\title{
Overestimation of the earthquake hazard along the Himalaya: constraints in bracketing of medieval earthquakes from paleoseismic studies
}

\author{
Shreya Arora and Javed N. Malik
}

\begin{abstract}
The Himalaya is one of the most seismically active regions of the world. The occurrence of several large magnitude earthquakes viz. 1905 Kangra earthquake (Mw 7.8), 1934 Bihar-Nepal earthquake (Mw 8.2), 1950 Assam earthquake (Mw 8.4), 2005 Kashmir (Mw 7.6), and 2015 Gorkha (Mw 7.8) are the testimony to ongoing tectonic activity. In the last few decades, tremendous efforts have been made along the Himalayan arc to understand the patterns of earthquake occurrences, size, extent, and return periods. Some of the large magnitude earthquakes produced surface rupture, while some remained blind. Furthermore, due to the incompleteness of the earthquake catalogue, a very few events can be correlated with medieval earthquakes. Based on the existing paleoseismic data certainly, there exists a complexity to precisely determine the extent of surface rupture of these earthquakes and also for those events, which occurred during historic times. In this paper, we have compiled the paleo-seismological data and recalibrated the radiocarbon ages from the trenches excavated by previous workers along the entire Himalaya and compared earthquake scenario with the past. Our studies suggest that there were multiple earthquake events with overlapping surface ruptures in small patches with an average rupture length of $\sim 300 \mathrm{~km}$ limiting Mw 7.8-8.0 for the Himalayan arc, rather than two or three giant earthquakes rupturing the whole front. It has been identified that the large magnitude Himalayan earthquakes, such as 1905 Kangra, 1934 Bihar-Nepal, and 1950 Assam, that have occurred within a time frame of 45 years. Now, if these events are dated, there is a high possibility that within the range of \pm 50 years, they may be considered as the remnant of one giant earthquake rupturing the entire Himalayan arc. Therefore, leading to an overestimation of seismic hazard scenario in Himalaya.
\end{abstract}

Keywords: Recalibration, Radiocarbon age, Seismic hazard scenario, Medieval earthquakes, Himalayan Frontal Thrust

\section{Introduction}

The Himalaya is a $2500 \mathrm{~km}$ long belt of mountains, which are the result of the progressive under thrusting of the Indian Plate beneath Tibetan Plate along Main Himalayan Thrust (MHT) (Zhao et al. 1993; Molnar and Tapponnier 1977). Global Positioning System (GPS) measurements indicate $4-5 \mathrm{~cm} /$ year of convergence rate between these two plates (Banerjee and Bürgmann 2002) of which $18 \mathrm{~mm} /$ year is accommodated by thrust

*Correspondence: javed@iitk.ac.in Department of Earth Sciences, Indian Institute of Technology Kanpur, Kanpur 208016, India systems along the Himalayan arc. Tectonic deformation has resulted in the formation of four major south-verging thrust systems viz. South Tibetan Detachment (STD), which separates Tibetan sedimentary and Higher Himalayan meta-sedimentary sequences, Main Central Thrust (MCT), which bounds the Higher Himalayan Crystalline rocks, and Upper Precambrian to Paleozoic rocks of Lesser Himalaya. MCT has not been observed to rupture the Quaternary deposits and is considered to be inactive (Nataka 1989; Valdiya 1992). Main Boundary Thrust (MBT) marks the southern edge of Lesser Himalaya. The southernmost thrust is Himalayan Frontal Thrust (HFT), which has displaced Tertiary and Quaternary alluvial 
and molasse sediments and is expressed as discontinuous range front scarps (Nakata 1972; Valdiya 1980, 1992). These fault systems are the result of the southward propagation of the Himalayan Front through time and each fault merges into the basal detachment fault, i.e., Main Himalayan Thrust (Zhao et al. 1993; Pandey et al. 1995). Based on the active fault topography, the MBT and HFT are considered as active (Nakata 1989; Valdiya 1980; Malik and Mohanty 2007). Historical archives indicate that Himalaya has experienced several damaging earthquakes of intensity $>\mathrm{XI}$ in the last millennium (Iyengar et al. 1999; Chitrakar and Pandey 1986). Instrumental records and geodetic data indicate that several earthquakes have occurred along the basal detachment and propagated southward to produce surface rupture at Himalayan Front such as 1934 Nepal-Bihar (Sapkota et al. 2013) (Fig. 1c), but few nucleate below the Higher Himalaya and produced ruptures in the higher reaches only, 1905 Kangra Earthquake is one such example which produced surface rupture along Kangra Valley Fault (KVF) (Fig. 2a) (Malik et al. 2015). The variable nature of the rupture pattern raises several questions: (a) does all stored strain developed due to India-Tibet convergence is released during a single event? (b) Is the strain accumulation similar along the entire Himalaya, or (c) how does the variation in the Himalayan strike and segmentation effects the variable rupture pattern?

In the last few decades, several paleo-seismological investigation has been carried out along the active HFT which has provided significant data to understand the occurrence of large magnitude earthquakes in the Himalayan region (Wesnousky et al. 1999; Malik and Nakata 2003; Lavé et al. 2005; Malik et al. 2008, 2010a, b, 2015, 2016; Kumar and Mahajan 2001; Kumar et al. 2006, 2010; Kumahara and Jayangondaperumal 2013; Sapkota et al. 2013; Yule et al. 2006; Bollinger et al. 2014, 2016; Jayangondaperumal et al. 2016; Mishra et al. 2016). However, there exist constraints in terms of their period of occurrence and in determining the extent of surface rupture.

In this paper, we have divided Himalaya into three zones, i.e., Northwestern Himalaya, Central Himalaya, and Eastern Himalaya to understand the pattern of occurrence of paleo-earthquakes (Figs. 1, 2, 3). The Northwestern Himalaya is further categorized into Kashmir sector, Kangra reentrant and Dehradun sector, Central Himalaya into Ramnagar sector, Western Nepal and Central Nepal and Eastern Himalaya into Eastern India (Figs. 1a, 3). Succession of earthquakes along these Himalayan zones from historical archives of (Oldham 1883; Iyengar et al. 1999; Pant 2002; Ambraseys and Douglas 2004) and the paleo-seismological data including timing, displacement of the latest event, and slip rates from the trench studies has been compiled (Bollinger et al. 2014, 2016; Gavillot et al. 2016; Jayangondaperumal et al. 2016; Kumar and Mahajan 2001; Kumar et al. 2006, 2010; Kumahara and Jayangondaperumal 2013; Kondo et al. 2008; Lavé et al. 2005; Meigs et al. 2012, Madden et al. 2011; Malik and Nakata 2003; Malik et al. 2008, 2010a, b, 2015, 2016; Mishra et al. 2016; Sapkota et al. 2013; Yule et al. 2006; Vassallo et al. 2015). An attempt has been made to highlight the problems of bracketing the ages and assigning a specific event to the surface ruptures along the Himalayan front, where other earthquake events with similar time frame could be fitted. Along with this, a scenario for past 100 years of Himalayan earthquakes has been compared to the earthquake scenario of the medieval times and the spatial extent of few medieval earthquakes has been debriefed.

\section{Seismicity}

During past few centuries, Himalaya has witnessed several moderate and large earthquakes with magnitudes $7.8 \leq \mathrm{Mw} \leq 8.4$ from these, and five events are considered as great earthquakes viz. 1934 Bihar-Nepal earthquake (Mw 8.2), 1950 Assam earthquake (Mw 8.4), 1951 (Mw 8) after shock of Assam earthquake, 1905 Kangra earthquakes (Mw 7.8), and $2015 \mathrm{Nepal}$ earthquake (Mw 7.8) (Seeber and Armbruster 1981; Pandey and Molnar 1988; Ambraseys and Bilham 2000; Ambraseys and Douglas 2004; Martin and Szeliga 2010; Bollinger et al. 2016) (Fig. 1a). Some of these earthquakes seem to have ruptured the upper brittle portion of the locked Main Himalayan Thrust (MHT) (Sapkota et al. 2013; Malik et al. 2015, 2016) and have produced surface ruptures along HFT. The location of rupture areas of these large earthquakes exhibits a Seismic Gap and one such example is between 1905 Kangra and 1934 Bihar-Nepal earthquakes which is termed Central Seismic Gap (Khattri 1987; Khattri and Tyagi 1983; Bilham et al. 1998; Bilham and Wallace 2005; Gupta and Gahalaut 2014) (Fig. 1a). This region has not experienced any great magnitude earthquake since 1344 event (Kumahara and Jayangondaperumal 2013; Rajendran et al. 2015; Malik et al. 2016) or probably the event has not been precisely documented in historical chronicles. Few large magnitude earthquakes $6.6 \geq \mathrm{Mw} \leq 7.8$ have occurred in this region such as 1991 Uttarkashi earthquake Mw 6.9, 1999 Chamoli earthquake Mw 6.6, 1803 Mw 7.2 in Central Himalaya, and $1833 \mathrm{Mw} 7.8$ with an epicenter in the inferred rupture zone of 1934 Bihar-Nepal earthquake (Bilham 1995) (Fig. 1a). It has been postulated that a great earthquake can follow a major earthquake in the Himalayan domain. This was suggested that in case of AD 1833 (Mw 7.8), a major earthquake was followed by 1934 AD (Mw 8.2) great earthquake in Nepal (Feldl and Bilham 2006). 


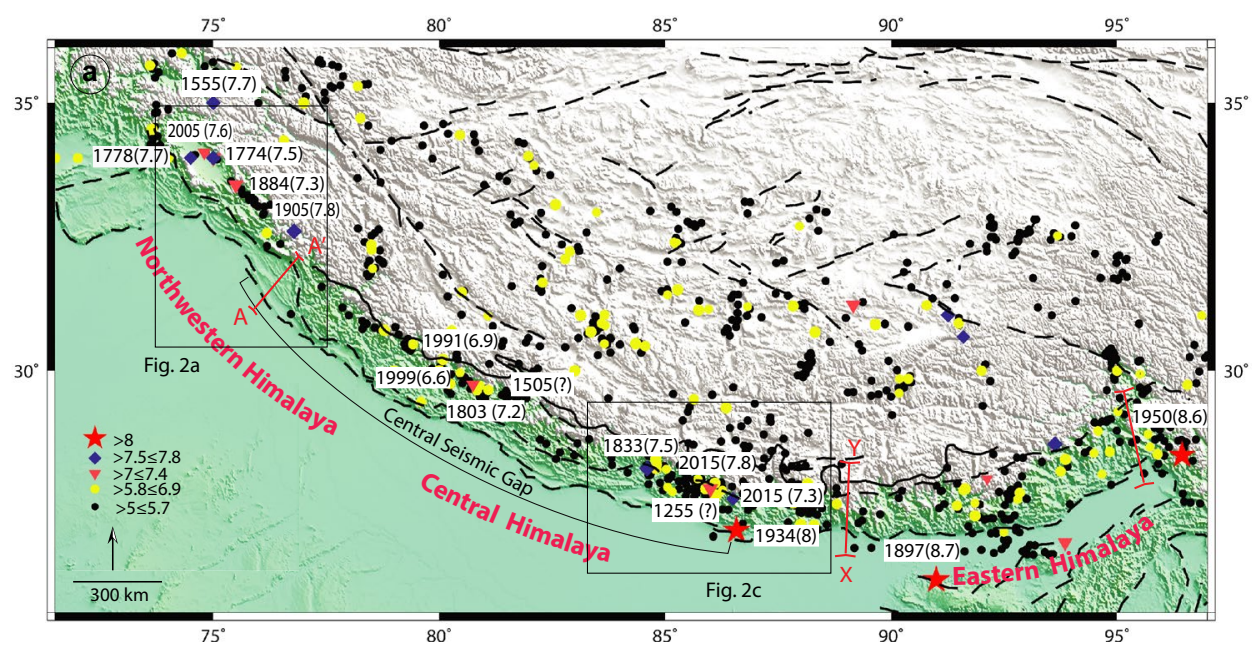

(b)

IGP

\section{UPPER SIWALIKS DUN LESSER HIMALAYAS HIGHER HIMALAYAS}

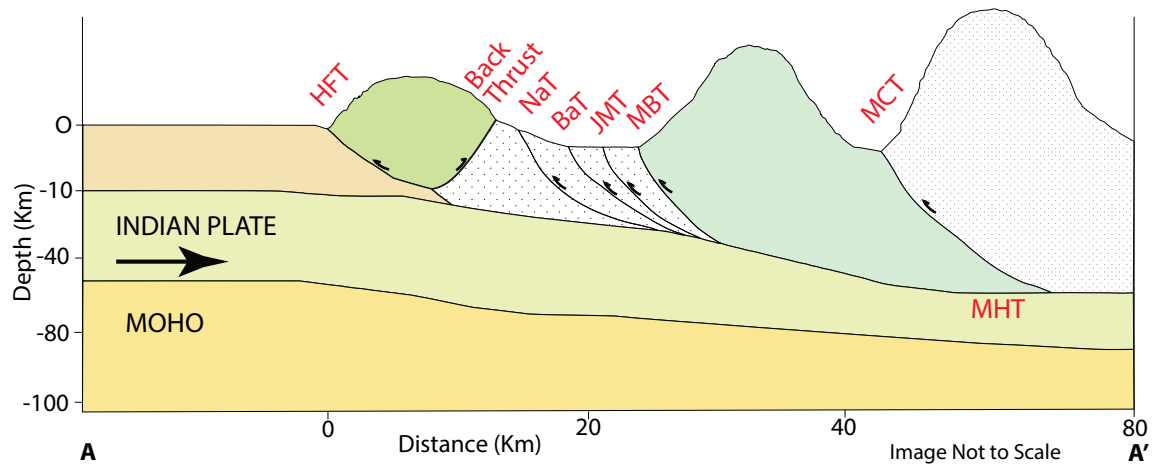

(c)

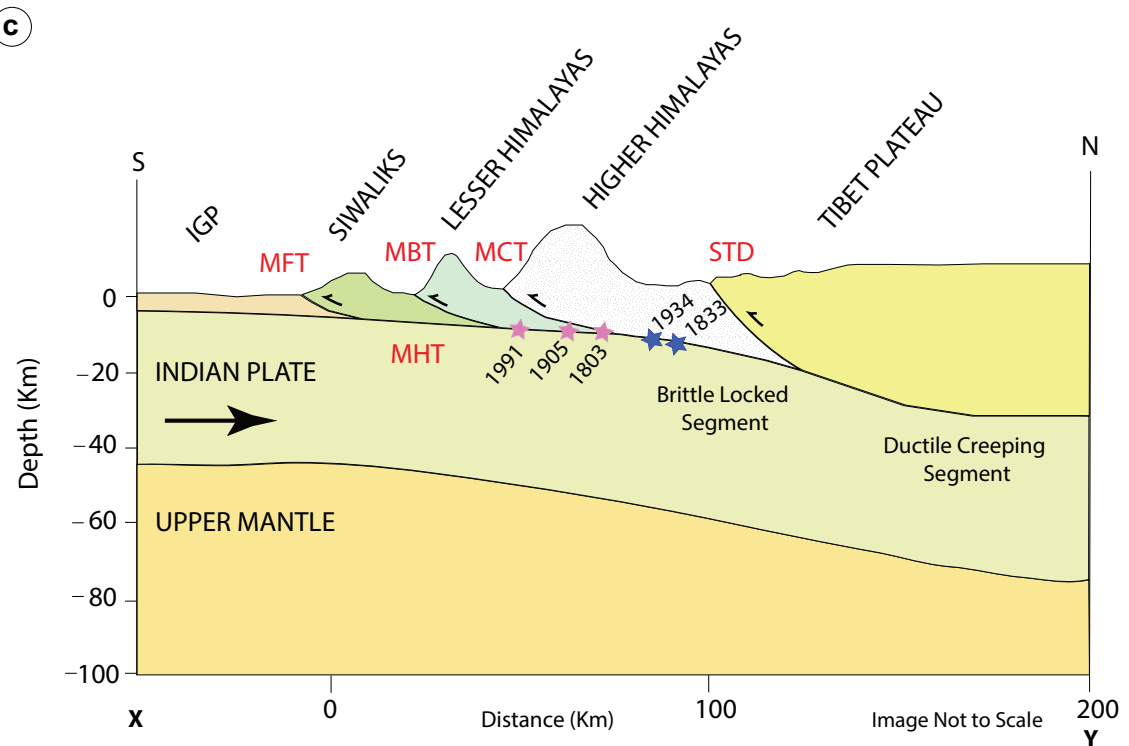

Fig. 1 a Map of the earthquakes of the last millennium in the Himalaya including the cross-section across the northwest and eastern Himalaya. b Schematic section A-A'showing the faults in northwest Himalaya. c Cross section along the eastern Himalaya pink and blue stars showing the recorded instrumental earthquake along the ramp and flat of MHT (modified from Mugnier et al. 2013) 
Present-day deformation rates in the Himalaya have been computed through GPS and geomorphological studies, which shows thrusting along the Himalayan Front absorbs $21 \pm 1.5 \mathrm{~mm}$ /year of $\mathrm{N}-\mathrm{S}$ shortening in central Nepal (Lavé and Avouac 2000), $19 \mathrm{~mm} /$ year in western Nepal (Mugnier et al. 1999), $14 \pm 2 \mathrm{~mm} /$ year in Kangra reentrant, and $11 \pm 5 \mathrm{~mm} /$ year across Dehra Dun (Powers et al. 1998). The decrease in the slip rates along the frontal Himalayan arc is attributed to the counter-clockwise rotation of the Indian plate with respect to the stable Eurasian plate (Bilham et al. 2001). In addition, other probable reasons could be oblique convergence (Malik and Nakata 2003; Malik et al. 2015; Kundu et al. 2014).

\section{Active fault and paleoseismic studies}

Identification and mapping of the active faults bear significant importance, because they provide the primary evidence of the style and kinematic of fault deformation. In this paper, studies on active faults are broadly divided into several sectors keeping in mind the variable strike of the Himalayan arc (Figs. 1, 2, 3).

\section{Northwest Himalaya \\ Kashmir sector}

Kashmir basin is a Neogene-Quaternary intermontane basin striking $150 \mathrm{~km}$ in length, where the major deformation is observed in the hinterland away from the front (Nakata 1989; Kaneda et al. 2006, 2008; Shah 2015) (Fig. 2a). The deformation in the basin is reflected in the form of a complex pattern of faulting that occurs around Pir Panjal range. The fault system includes MCT, Medlicott Wadia Thrust (MWT), MBT, Riasi Thrust (RT), Kotli Thrust (KT), Balapur Fault (BF), and HFT (Fig. 2a), of which MBT is considered inactive since at least $\sim 30 \mathrm{ka}$ (Vassallo et al. 2015). Whereas, MWT, KT, BT, and HFT are seismically active, as revealed by the geomorphic index studies (Ahmad et al. 2013; Alam et al. 2015; Shabir and Bhat 2012; Dar et al. 2014; Vassallo et al. 2015). The presence of tilted fluvio-lacustrine deposits and clear fault scarps cutting quaternary deposits is the key features, suggesting recent tectonic activity in the region (Ahmad et al. 2013).

Extensive studies were carried out on a major out-ofsequence BF, which lies in the Kashmir Valley bounded to the south by Pir Panjal ranges and to the north by Higher Himalaya (Fig. 2a). Drainage anomalies such as stream capture and drainage deflection of Dudhganga, Shaliganga, and Sukhnag Rivers suggest that the fault is active and the basin is still evolving (Ahmad and Bhat 2012; Dar et al. 2014). Balapur Fault has deformed several strath terraces along the Shaliganga River and caused tilting of the Kashmir Basin towards SE (Shah 2015). This fault runs for $\sim 110 \mathrm{~km}$ in length and can host a devastating earthquake of Mw 7.6 similar to Muzaffarabad earthquake (Shah 2015).

A right-lateral strike-slip fault striking NNW-SSE for $\sim 170 \mathrm{~km}$ named Central Kashmir Fault (CKF) is evidenced by the offsetting of the Chenab River in north and Kishanganga River in the south. More prominent pullapart basins have been reported in the valley along this fault (Alam et al. 2015).

Optically Stimulated Luminescence (OSL) ages on the higher undeformed terrace of the Shaliganga River shows that the Balapur Fault has not moved since $50 \pm 3 \mathrm{ka}$ (Ahmad and Bhat 2012). The average incision rate on $19 \mathrm{~m}$ high strath terrace is $0.3-1.5 \mathrm{~mm} /$ year (Madden et al. 2011). Paleoseismic investigation on BF revealed two events between 1.5 and $18.7 \mathrm{ka}$, another between 33.4 and $38.4 \mathrm{ka}$, and as many as four events around $40 \mathrm{ka}$ (Madden et al. 2011). The most recent slip on the $\mathrm{BF}$ is assumed to have occurred around $1 \mathrm{ka}$ (Meigs et al. 2012).

Trench investigation at Balakot Bagh Fault (BBF) (Fig. 2a) after the 2005 Muzaffarabad earthquake revealed recurrence interval of $\sim 2 \mathrm{ka}$, shortening rate and slip rate of $1.2-4.1$ and $\sim 3 \mathrm{~mm} /$ year, respectively (Kondo et al. 2008). Recent studies on Riasi Thrust indicate a cumulative vertical separation of $272 \pm 10 \mathrm{~m}$ and shortening rate of $5.6 \pm 2.8-7.1 \pm 4.06 \mathrm{~mm} /$ year in last $100 \mathrm{ka}$ (Gavillot et al. 2016).

Seismic activity in the Kashmir Valley due to 1555 , 1885,1963 , and 2013 earthquakes is attributed to the tectonic activity along CKF as the epicenters of these earthquakes are located in NNW and SSE extensions of the Kashmir basin corresponding to the direction along CKF (Alam et al. 2015). The accumulated strain in the 2005 rupture area corresponds to Mw 8.0, with a slip of $>6 \mathrm{~m}$ which has not fully released during the 2005 event increasing the likelihood of another similar event in the region (Kondo et al. 2008).

\section{Kangra reentrant}

This region of the NW Himalaya is classified into four geomorphological zones from north to south (1) lower Siwalik mountains comprising Tertiary rocks of Dagshai, Kausali, and Subathu Formation, (2) intermontane valley consisting of Late Pleistocene to Holocene sediments overlying the Lower Siwalik bedrock, i.e., Pinjore Dun and Soan Dun, (3) Upper Siwalik hills comprising of conglomerates and mudstones, and (4) Indo-Gangetic Plain (Fig. 2b). The boundaries between the geomorphic zones are marked by the complex fault system. The Tertiary rocks have undergone intense brittle deformation along various major faults (Raiverman et al. 1994). From the north Palampur Thrust (PaT), Bilaspur Thrust 





(BT), Jawalamukhi Thrust (JMT), Nalagarh Thrust (NaT), and Barsar Thrust (BaT) (Figs. 1b, 2b) form an imbricate thrust of MBT (Middlemiss 1910; Thakur et al. 2010; Suresh et al. 2007). Nalagarh Thrust and Barsar Thrust stretch from Pinjore Dun to Soan Dun and separate the dun from the Lower Siwalik. The faults are expressed in the form of discontinuous scarps along the mountain front (Malik and Mohanty 2007) (Fig. 2a, b). The Pinjore Garden Fault (PGF) and the Sirsa Fault are located in the hinterland of the Upper Siwalik and separates it from the Pinjore Dun (Fig. 2a). The southernmost fault, i.e., HFT, separates Upper Siwalik from the Indo-Gangetic Plain.

\section{Hajipur}

The NW-SE trending of Janauri and Chandigarh anticlines are the result of fault-propagation folding due to the long-term tectonic activity along HFT (Powers et al. 1998; Singh and Tandon 2008; Delcaillau et al. 2006; Malik and Mohanty 2007) (Fig. 2b). Several wellpreserved active fault scarps have been reported in the northern and central part of the Janauri and Chandigarh anticline (Malik and Mohanty 2007; Malik and Nakata 2003; Kumar et al. 2010). Two active faults HF1 and HF2 striking NNW-SSE along the northwestern fringe of the Janauri anticline have been identified. The fault scrap runs parallel to the trend of the Himalayan arc on the left bank of the Beas River (Fig. 2a) (Malik and Mohanty 2007). The scrap height varies from 2 to $15 \mathrm{~m}$ along the strike, with a higher elevation near the range front and gradual reduction in NNW direction (Malik et al. 2010a, b). The scrap along HF1 is highly degraded as compared to HF2 indicating younger activity on HF2. The formation of these scraps is attributed to the lateral propagation of the fault-related folding along HF1 and HF2 (Malik et al. 2010a, b). A prominent south-facing back thrust scarp is reported near Bhatpur village, perpendicular to the direction of the river channel is suggestive of ongoing deformation along HFT (Malik et al. 2010a; Kumahara and Jayangondaperumal 2013).

Paleoseismic investigation along HF2 scarp near Hajipur village revealed a net displacement of $9 \mathrm{~m}$ during a single event and a slip rate of $7.6 \pm 1.7 \mathrm{~mm} /$ year (Fig. 3). The OSL and radiocarbon ages from the trench suggest that the most recent event would have occurred between 1500 and $1600 \mathrm{AD}$ (Malik et al. 2010a, b). Another paleoseismic investigation across the HFT near Bhatpur village (Fig. 3) revealed a cumulative slip of $9.3 \mathrm{~m}$ and based on the charcoal ages, it has been suggested that the latest faulting event occurred between 1400 and $1460 \mathrm{AD}$ (Kumahara and Jayangondaperumal 2013). In addition, the trench investigation carried across a $2 \mathrm{~m}$ high scarp along the back limb of the Janauri anticline on the back thrust near Mehandpur village suggests that the most recent event occurred during $1344 \mathrm{AD}$. Furthermore, it has been postulated that surface ruptures recorded on the forelimb and on the back limb (back thrust) are contemporary and have occurred during the same time span, which has been correlated with an earthquake event of 1344 AD (Jayangondaperumal et al. 2016).

\section{Kangra}

A strike-slip fault striking NNW-SSE and extending for $60 \mathrm{~km}$ has been identified in the meizoseismal zone of the 1905 Kangra earthquake in the Kangra town and has been named as Kangra Valley Fault (KVF) (Malik et al. 2015) (Fig. 2a). The discontinuous active fault traces in Kangra Valley have displaced fluvial terraces and alluvial fan surfaces giving rise to north and south-facing fault scarps. Stream offsets measuring $350 \mathrm{~m}$, linear valleys, and pressure ridges were the prominent active fault topographic features identified along this fault.

A paleoseismic study along KVF in the Kangra Valley revealed at least four major earthquakes occurred along this fault. On the basis of OxCal v.4.2.4 model (Ramsay et al. 2013), the Event I occurred before 900 BC, Event II between $890 \mathrm{BC}$ and $720 \mathrm{AD}$, Event III between 750 and $1290 \mathrm{AD}$, and Event IV after $1620 \mathrm{AD}$ and before 1940 AD, indicating 1905 Kangra earthquake as the most probable recent event (Malik et al. 2015). Based on the time gap between respective events, a recurrence interval of 2000 years has been suggested between Events I and II and a shorter interval of about $1050 \pm 50$ years between Events II-III and III-IV (Malik et al. 2015).

According to DeMets et al. (1994), when a tectonic plate subducts at an angle that is oblique to the trend of a trench, the trench parallel component decouples fore-arc slivers from the overlying plate and causes trench translation. India-Eurasia convergence is arc normal in the Central Himalaya, but to the west, it becomes oblique to the regional Himalayan structural trend (Malik and Nakata 2003; Kundu et al. 2014). This obliquity results in a shear component, which is manifested in the form of strikeslip faults. The identification of the KVF bears significant importance in corroborating the concept of oblique convergence and instituting it into northwest Himalaya (Malik et al. 2015).

\section{Chandigarh}

The surface expression of the active fault traces along HFT is discontinuous and has vertically displaced Late Pleistocene to Holocene alluvial fan surfaces resulting in a sharp southwest facing scarps. On the right bank of the Ghaggar River, two parallel fault scarps with 15-38 m elevation have been identified and named Chandigarh Fault (CF) (Nakata 1989; Malik and Nakata 2003) (Fig. 2a). The Chandigarh Fault has displaced Ghaggar, Kalka, Pinjore, and Koshallia 


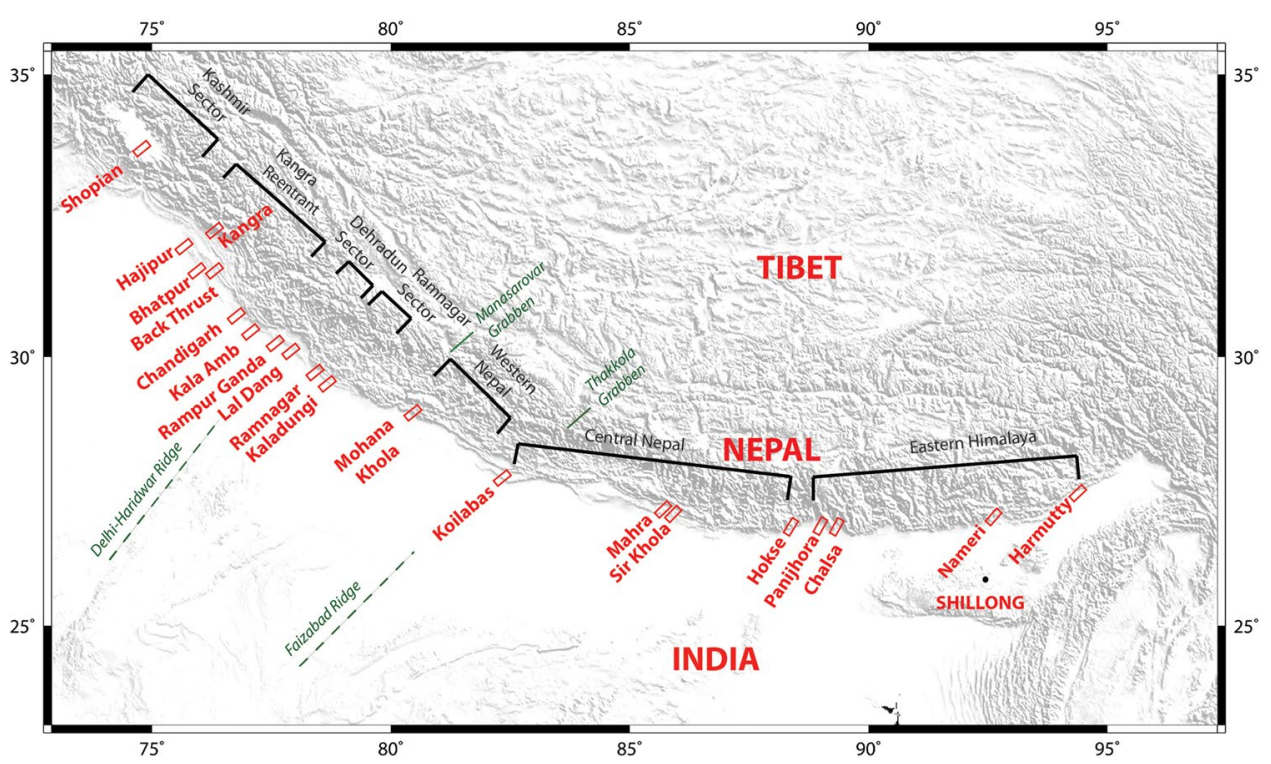

Fig. 3 Paleoseismological trench sites investigated by (Bollinger et al. 2014, 2016; Gavillot et al. 2016; Jayangondaperumal et al. 2016; Kumar and Mahajan 2001; Kumar et al. 2006, 2010; Kumahara and Jayangondaperumal 2013; Kondo et al. 2008; Lavé et al. 2005; Meigs et al. 2012; Madden et al. 2011; Malik and Nakata 2003; Malik et al. 2008, 2010a, b, 2015, 2016; Mishra et al. 2016; Sapkota et al. 2013; Yule et al. 2006; Vassallo et al. 2015) at the frontal and the hinterland faults of Himalaya

terraces (Malik and Nakata 2003) except the younger modern river terrace, which is about $14 \mathrm{~m}$ above the present river channel. Based on the charcoal age of 1036-1401 AD from the Lower Terrace (Koshallia surface) along Ghaggar River, a maximum incision rate of $\sim 4-6 \mathrm{~mm}$ /year has been suggested in this region (Kumar et al. 2006).

Paleoseismic investigation at the base of $16 \mathrm{~m}$ high fault scarp of CF revealed $3.5 \mathrm{~m}$ of total displacement and an evidence of most recent event during 1400-1500 AD (Malik and Nakata 2003; Malik et al. 2008). Whereas, another trench excavated by Kumar et al. (2006) suggested an event around 1404-1628 AD. The intact masonry structure of Pinjore Garden, which was built by Mughals in the 17 th century, suggests that no major earthquake strucks this region during that period or later (Fig. 2b). Based on the OSL dates, it has been estimated that the fan deposition in the Pinjore Dun initiated before $85 \pm 7.2 \mathrm{ka}$ and terminated after $67 \pm 8.4 \mathrm{ka}$ (Phillip et al. 2011). Another trench excavation across $6 \mathrm{~m}$ high scarp along Pinjore Garden Fault (PGF) in Pinjore Dun revealed the occurrence of at least two major earthquake events with a total displacement of $2.85 \mathrm{~m}$ and a net displacement of $2 \mathrm{~m}$ during one single event (Malik and Mathew 2005). OSL ages from this trench on PGF suggest that Event I occurred after $10 \mathrm{ka}$ and most recent event II occurred after $4 \mathrm{ka}$ (Malik 2006).

At $\sim 40 \mathrm{~km}$ southeast of Chandigarh city, HFT takes a sharp bend towards right near the Kala Amb city. This sharp bend is due to the presence of a tear fault named Black Mango Tear Fault (BMF) (Fig. 2a), which has truncated and uplifted the terraces of the Markanda River (Kumar et al. 2001). The terrace sits about $27 \mathrm{~m}$ above the present river channel, and suggested that incision rate is around $4 \mathrm{~mm} /$ year (Kumar et al. 2006). Trench excavation on the Black Mango Fault scarp revealed three surface rupturing events with $5.4 \mathrm{~m}$ coseismic slip during 1294 AD event, 2.4-4.0 m during 1423 AD, and possibly larger displacement for the $260 \mathrm{AD}$ event (Kumar et al. 2006).

\section{Dehradun sector}

The two major rivers Ganga and Yamuna flowing across Dehra Dun has resulted in the formation of several fluvial terraces. Nakata (1972) identified two major surfaces, i.e., Middle Dun Surface and Lower Dun Surface on the basis of the drainage texture. Valdiya (1992) identified two levels of uplifted terraces in the valley of Kosi River near Ramnagar having an elevation of 35 and $25 \mathrm{~m}$, respectively. These terraces have been uplifted in two events as marked by deformed clasts (Valdiya 1992). Several southfacing fault scarplets cutting the alluvial fan surfaces confirm the activity along HFT (Yeats et al. 1992). Assuming the $30^{\circ}$ dip of HFT as indicated by seismic reflection data, and radiocarbon ages from the displaced surfaces suggest $13.8 \pm 3.6 \mathrm{~mm} /$ year of slip rate on HFT (Wesnousky et al. 1999). 
Discontinuous scarplets of the Mohand Thrust which is a segment of HFT have displaced Quaternary alluvium at Rampur Ganda and at Lal Dang located $\sim 24 \mathrm{~km}$ south and $\sim 50 \mathrm{~km}$ southeast of Dehra Dun, respectively. The charcoal sample recovered from the faulted youngest unit from Rampur Ganda trench suggested that the recent event occurred around 1319-1380 and 1310$1442 \mathrm{AD}$ (Fig. 3). The event on the fault was bracketed between 1222 and $1442 \mathrm{AD}$, with $8.0 \mathrm{~m}$ of vertical separation (Kumar et al. 2006). The paleoseismic data from the trench at Lal Dang suggested the latest event between 1282 and $1632 \mathrm{AD}$ with a vertical separation of $9.0 \mathrm{~m}$ (Kumar et al. 2006). A total slip of 16-18 m from Rampur Ganda and Lal Dang by Kumar et al. (2006) has been attributed to an event of 1344 AD (Mugnier et al. 2013).

\section{Central Himalaya}

\section{Ramnagar sector}

Recent efforts in the Central Himalaya have revealed several evidences of the surface ruptures of paleo-earthquakes. Trench excavation by Kumar et al. (2006) on HFT near Ramnagar reported the evidence of surface rupture due to an event between 1259 and $1390 \mathrm{AD}$ suggesting an event prior to $1433 \mathrm{AD}$, but after $1278 \mathrm{AD}$ with total vertical separation of $13 \mathrm{~m}$ (Fig. 3). Trench excavation across Kaladungi Fault-a branching out fault from HFT-suggested that Event I occurred between 467 BC and 570 AD; Event II between 1294 and 1587 AD, and Event III, the Most Recent Event between 1750 and 1932 AD (Malik et al. 2016). Another trench excavation at Belparao village near Ramnagar across $13 \mathrm{~m}$ high scarp suggested that the slip along the faults in the trench is due to two earthquakes (Rajendran et al. 2015). They suggested that an older event around 1050-1259 AD and the younger event around 1259-1433 AD (Rajendran et al. 2015). These events are correlated with the two damaging earthquakes of 1255 AD sourced in Nepal and 1344 AD sourced in the Indian part of the Central Himalaya (Sapkota et al. 2013; Mugnier et al. 2011, 2013). The recent paleo-seismological studies by Malik et al. (2016) inferred that the segment of the HFT in Ramnagar ruptured thrice during 1344 or $1400 \mathrm{AD}, 1505 \mathrm{AD}$ and during $1803 \mathrm{AD}$ earthquakes. The report of surface rupture of $1803 \mathrm{AD}$ at Ramnagar has helped in refining the earthquake hazard scenario in the Central Himalaya and adjacent Indo-Gangetic Plain.

\section{Western Nepal}

Soft-sediment deformation is an important proxy to identify the timing of earthquakes, as the seismic waves induce shearing between the planes parallel to the surface cause fluidization in the soft sediments producing dikes and ball-pillow structures (termed seismites) as well as sand blows. Evidence of seismites from the Kathmandu valley and along MFT was compared and provided the evidence of three mega-events that occurred during the 12th, 13th, and 15th centuries, i.e., Mw 8.6 event in 1100 AD in eastern Nepal, 1255 AD event in western Nepal, and an event with magnitude $>\mathrm{Mw} 8.6$ occurred during 1408 AD in far-western Nepal (Mugnier et al. 2011). Extending the studies into far-western Nepal at Mohana Khola, trench excavation (Fig. 3) across $7 \mathrm{~m}$ scarp on MFT provided an evidence of $1505 \mathrm{AD}$ surface ruptures on the basis of the charcoal dating of the soil sample collected from the trench (Yule et al. 2006; Hossler et al. 2016).

\section{Central Nepal}

Several efforts have been made in the Central Nepal region that was struck by large earthquakes like 1833, $1934 \mathrm{AD}$ and the recent 2015 Gorkha earthquake to estimate the surface ruptures and constrain the timing of last and penultimate events (Bilham 1995; Campbell 1833a, b; Dunn et al. 1939; Hayes et al. 2015). Clear evidence of the surface deformation along the river-cut cliff in the east of Mahara River and presence of six levels of terraces along Bardibas and Patu Thrust suggested coseismic uplift (Sapkota et al. 2013). Trench excavation on Sir Khola across the Patu Thrust along Sir River revealed two surface ruptures resulted from 1255 and 1934 AD earthquakes (Sapkota et al. 2013) (Fig. 3). It has been reported that about one-third of the population of Kathmandu was killed during 1255 AD earthquake (Pant 2002). The rupture of the $1934 \mathrm{AD}$ earthquake propagated $150 \mathrm{~km}$ east-west overlapping with the $1833 \mathrm{AD}$ epicenter with $\sim 50 \mathrm{~km}$ common segment which must have moved during both these events (Bilham 2004, Mugnier et al. 2013). Folded sediments at the border of India and Nepal near Hoske reveal a slip of $>4 \mathrm{~m}$ which has been attributed to 1255 AD earthquake (Bollinger et al. 2016).

\section{Eastern Himalaya \\ Eastern India}

With the motive to refine surface rupture data of the past earthquakes and filling the gaps of the historical archives in the northeast Himalaya, several trenches have been excavated across the discontinuous scarps along HFT (Kumar et al. 2010; Mishra et al. 2016). The results of all the trench at Panijhora, Chalsa, Nameri, and Harmutty in Darjeeling Himalaya suggested that paleo-earthquake in this region postdate $1152 \mathrm{AD}$, but before $1378 \mathrm{AD}$, assigning $1255 \mathrm{AD}$ event to be a mega event that ruptured the entire $800 \mathrm{~km}$ Himalayan arc (Kumar et al. 2010; Mishra et al. 2016) (Fig. 3). 


\section{Discussion}

In the past few years, several paleo-seismological studies by different researchers have been performed along the Himalayan front (Bollinger et al. 2014, 2016; Gavillot et al. 2016; Meigs et al. 2012; Madden et al. 2011; Malik and Nakata 2003; Lavé et al. 2005; Malik et al. 2008, 2010a, b, 2015, 2016; Mishra et al. 2016; Kumar and Mahajan 2001; Kumar et al 2006, 2010; Kumahara and Jayangondaperumal 2013; Kondo et al. 2008; Sapkota et al. 2013; Yule et al. 2006; Jayangondaperumal et al. 2016; Vassallo et al. 2015). Compilation and recalibration of the AMS and OSL ages from the excavated trenches helped us in delineating the extent of rupture length of the historical earthquakes, as well as made it possible to discuss the limitation of bracketing the event based on paleoseismic investigations. We used OxCal 4.2 online program with Bayesian analysis (Ramsay 1995; Ramsay et al. 2013) for all the samples from the trenches. The ages are processed with Markov Chain Monte Charlo model at $94.5 \%$ confidence level. For the analysis, samples from the youngest faulted and from the capping units were considered excluding the reworked samples. Wherever possible in the trenches, to bracket the earthquake event, maximum age of the capping unit and the minimum age of the deformed unit are considered. The results are displayed in the form of probability density function graph (multiplot) and the ages are arranged according to the samples collected in trenches from west to east of the Himalaya (Fig. 4a). To show the clustering of the events, only the ages from the capping unit is considered (Fig. 4b). The information on ages, their uncertainty, mean ages, and source of data are displayed in the form of a table (Table 1).

\section{Historical earthquakes and ruptures}

To estimate the extend of the rupture length of the historical earthquakes, OSL and AMS ages obtained from trenches excavated in Kangra valley in the west to Harmutty in the east of Himalaya were compiled and recalibrated (Fig. 4a, b). The results helped us in bracketing four major events those were experienced during historical period along Himalaya. The curves from the model suggest events occurred around 1250-1440 AD at Bhatpur, Chandigarh, Hajipur, Rampur Ganda, Ramnagar, Belparao, Harmutty, and Sir trench. Event around 1490-1600 AD at Hajipur, Kaladungi, and Lal Dang, and earthquake event post-dating 1040-1220 AD at Chalsa, Nameri, and Panijhora (Fig. 4b; Table 1). From the calibration results, it is possible to correlate the most recent event in the context of the spatial clustering (Fig. 4b). Whereas, events with the same time frame are marked by the colored rectangular boxes (Fig. 4b).
The historical records of the earthquakes in Nepal and India are rather incomplete, and difficult to reconcile. However, earthquakes like 1255 and 1408 AD are well documented, with an ambiguity in epicenters. According to the historians on June of $1255 \mathrm{AD}$, a violent earthquake shook the Katmandu Valley killing one-third of the entire population along with the King Abhaya Malla himself (Pant 2002). During September 1408 or 1344 $\mathrm{AD}$, another major earthquake strucks the Kathmandu Valley destroying the temples and buildings along with cracks on the surface (DPNet Nepal report 2015). The previously cited $1408 \mathrm{AD}$ event by Chitrakar and Pandey (1986) is considered to be same as 1344 AD event (Pant 2002). The exact epicenter of 1408 or 1344 AD is not well defined, but according to the OxCal recalibrated radiocarbon ages from the trenches, the event can be correlated to the surface rupture in the Bhatpur, Chandigarh, Rampur, and in Ramnagar trenches extending its rupture length to more than $1000 \mathrm{~km}$ from Kathmandu Valley to Bhatpur in northwest Himalaya, validated by identified surface rupture from the back thrust along the Janauri anticline (Jayangondaperumal et al. 2016).

The surface rupture of $1255 \mathrm{AD}$ earthquake reported from the Sir trenches in Central Nepal (Sapkota et al. 2013) has been extended up to far east to Harmutty in the eastern part India (Mishra et al. 2016) or at least to Hokse in eastern Nepal by Bollinger et al. (2016). The $1255 \mathrm{AD}$ is assigned to be a giant earthquake rupturing $\sim 800 \mathrm{~km}$ of the Himalayan arc (Mishra et al. 2016). The recalibrated mean ages of the earthquake events obtained from Panijhora, Chalsa, and Nameri are 1060, 1201, and $1126 \mathrm{AD}$, respectively (Table 1). The stratigraphy from the trench at Panijhora suggests that Most Recent Event has occurred after the deposition of the unit from which sample for AMS dating was collected (Mishra et al. 2016). Thus, 1255 and $1100 \mathrm{AD}$ earthquakes are the plausible candidates at that location testing the interpretation of Mishra et al. (2016). Similar interpretation can be made for the Nameri and Chalsa trenches, where the event postdates the ages obtained from the charcoal sample. The trenches at Belparao (Ramnagar) and Sir Khola confirm with the age range in which the earthquake 1255 $\mathrm{AD}$ can be bracketed, as the sample collected for bracketing was from the unit deformed after or during the earthquake event. The extent of the $1255 \mathrm{AD}$ rupture to Hokse needs more clarification as the marker sample of charcoal from the un-faulted unit yielded the late 13th and 15th to the 16th century ages (Upreti et al. 2000), signaling the possibility of 1100,1223 , and $1255 \mathrm{AD}$ event in the region.

The identification of 1505 AD surface rupture at Mohana Khola (Yule et al. 2006) and historical reports 

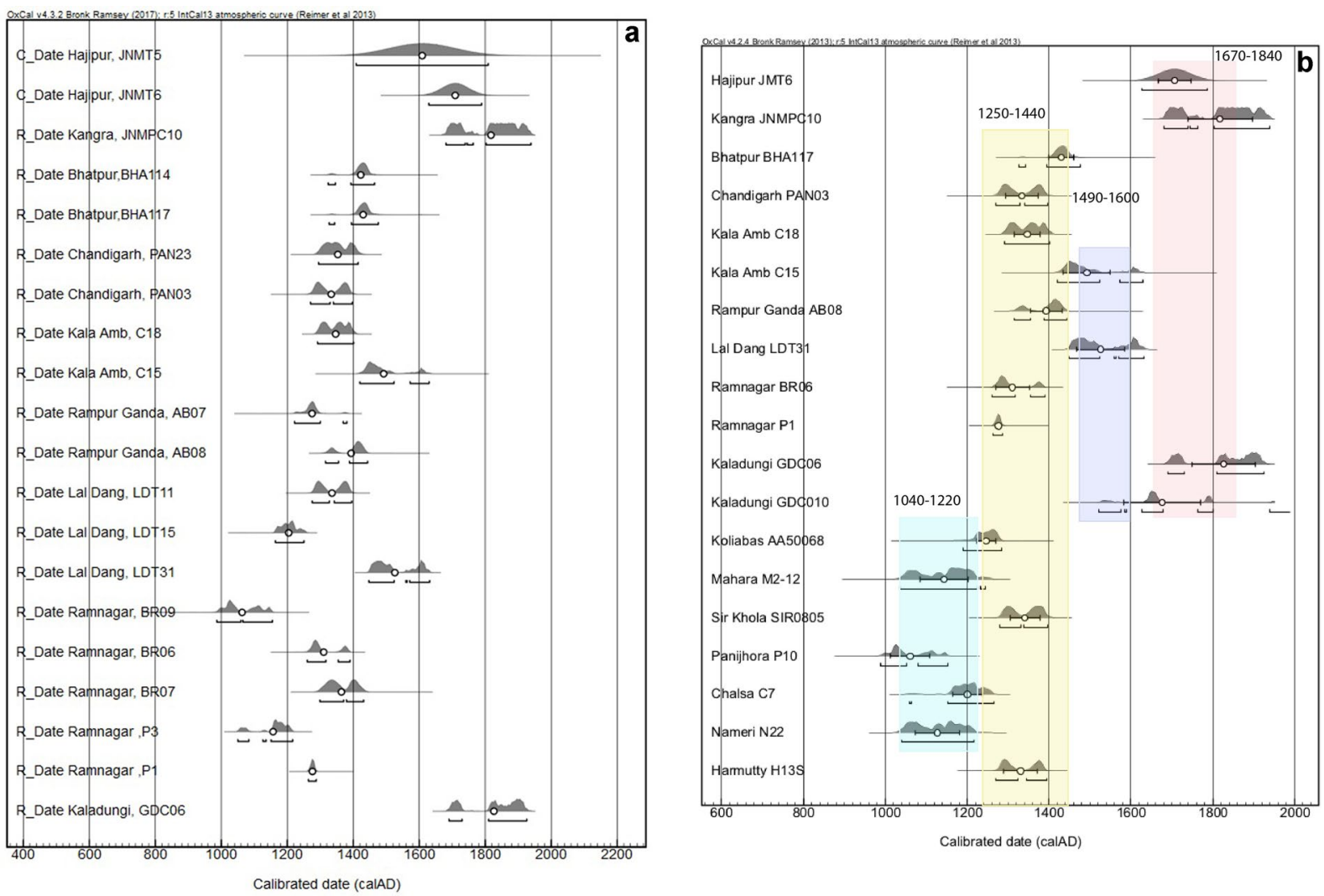

Fig. 4 a Calendar ages and probability density function graph of the events arranged according to the samples collected in trenches dug from west to east of Himalaya are modelled using OxCal v.4.2.4 (Ramsay 1995; Ramsay et al. 2013). The information on ages, their uncertainty, mean ages, and source of data (references) are displayed in the form of a table (Table 1). b Open circle signifies mean age and the rectangular boxes incorporate areas with same age range and their spatial extent is decided to include mean ages. The calibrated age range shows that distinct evidence of 1344 event at Chandigarh, Ramnagar, and Belparao trench, Sample SIR0805 \& P10 postdate the 1255 AD event, and sample LDT31 \& GDC09 suggests 1505 AD event in Kaladungi and Lal Dang trenches

of the damage from Tibet to Agra led to speculation that $1505 \mathrm{AD}$ event could have ruptured up to $600 \mathrm{~km}$ (Bilham and Wallace 2005). The recalibrated radiocarbon age interval 1447-1631 AD at $94.5 \%$ confidence level from the Lal Dang trench indicates that the rupture of the $1505 \mathrm{AD}$ could have reached up to Lal Dang (Table 1). The recent paleo-seismological work by Malik et al. (2016) on the Kaladungi Fault, at Ramnagar attest to three events in the region, i.e., 1344/1400, 1505, and $1803 \mathrm{AD}$, strengthening the concept of Feldl and Bilham (2006) in the northwest Himalaya. It has been suggested from the trench data that a large magnitude event was followed by a great earthquake of $1505 \mathrm{AD}$ which ruptured Central Himalaya as also reported by Yule et al. (2006); Hossler et al. (2016). This event was followed by 1803 AD event, which was a large magnitude earthquake conforming to the possibility of another great earthquake in this region (Malik et al. 2016). The absence of any records of damage in Kathmandu in 1505 AD limits its extent from Koilabas in the east to
Mahakali-Mansarovar graben (Bollinger et al. 2016) (Fig. 3). Thus, it can be inferred that the $1505 \mathrm{AD}$ event ruptured at least $\sim 110 \mathrm{~km}$ from the western Nepal to Lal Dang in western portion of Central Himalaya.

Another devastating earthquake sourced in Kashmir Valley occurred on September 1555 AD with reports of huge holes on the ground and outpouring of springs (Iyengar et al. 1999). Recalibrating the OSL ages in OxCal from the faulted and capping units from Hajipur trench in northwest Himalaya suggests the paleo-earthquake range of 1426-1700 AD in which event of $1555 \mathrm{AD}$ can be bracketed (Table 1). Trench excavation on Chandigarh Fault suggested event around 1400-1500 AD (Malik and Mathew 2005). Considering this trench data, it can be suggested that the $1555 \mathrm{AD}$ rupture extended for $\sim 150 \mathrm{~km}$.

\section{Age bracketing problem}

According to the recalibrated radiocarbon ages and the work done by several previous workers, it can 
Table 1 List of all the recalibrated radiocarbon OSL ages and references of the samples collected from the trenches excavated by previous workers

\begin{tabular}{|c|c|c|c|c|c|}
\hline Trenches & Sample number & Measured radiocarbon age & Calibrated ages cal AD & Mean $(\mu)$ & References \\
\hline Hajipur & & & & & Malik et al. (2010a) \\
\hline Undeformed unit & JMT6 & $300 \pm 40$ & $1426-1700$ & 1707 & \\
\hline \multicolumn{6}{|l|}{ Kangra } \\
\hline Undeformed unit & JNMPC10 & $110 \pm 30$ & $1681-1938$ & 1817 & Malik et al. (2015) \\
\hline Bhatpur & & & & & $\begin{array}{l}\text { Kumahara and Jayangondaperumal } \\
\text { (2013) }\end{array}$ \\
\hline Undeformed unit & BHA-117 & $480 \pm 40$ & $1327-1476$ & 1429 & \\
\hline Chandigarh & & & & & Kumar et al. (2006) \\
\hline Undeformed unit & PAN-03 & $665 \pm 40$ & 1270-1397 & 1333 & \\
\hline \multirow[t]{3}{*}{ Kala Amb } & & & & & Kumar et al. (2001) \\
\hline & $\mathrm{C} 18$ & $620 \pm 30$ & $1292-1401$ & 1346 & \\
\hline & $\mathrm{C} 15$ & $420 \pm 40$ & $1420-1630$ & 1492 & \\
\hline Rampur Ganda & & & & & Kumar et al. (2006) \\
\hline Undeformed unit & AB08 & $530 \pm 35$ & $1316-1443$ & 1393 & \\
\hline Lal Dang & & & & & Kumar et al. (2006) \\
\hline Undeformed unit & LDT-31 & $375 \pm 25$ & $1447-1631$ & 1526 & \\
\hline Ramnagar & & & & & Kumar et al. (2006) \\
\hline Undeformed unit & BR-06 & $695 \pm 35$ & $1444-1634$ & 1526 & \\
\hline Ramnagar & & & & & Rajendran et al. (2015) \\
\hline Undeformed unit & $P-1$ & $727 \pm 16$ & $1264-1287$ & 1276 & \\
\hline Kaladungi & & & & & Malik et al. (2016) \\
\hline Deformed unit & GDC06 & $80 \pm 30$ & 1690-1926 & 1826 & \\
\hline Undeformed unit & GDC010 & $250 \pm 30$ & $1521-1939$ & 1676 & \\
\hline Koliabas & & & & & Mugnier et al. (2005) \\
\hline $\begin{array}{l}\text { Deformed River Ter- } \\
\text { race }\end{array}$ & AA50068 & $775 \pm 35$ & $1190-1285$ & 1246 & \\
\hline Mahara & & & & & Lavé et al. (2005) \\
\hline Undeformed unit & M2-12 & $880 \pm 40$ & $1036-1245$ & 1143 & \\
\hline \multirow[t]{2}{*}{ Sir Khola } & & & & & $\begin{array}{l}\text { Sapkota et al. (2013); Bollinger et al. } \\
\text { (2014) }\end{array}$ \\
\hline & SIR08-05 & $645 \pm 35$ & 1280-1398 & 1340 & \\
\hline Panijhora & & & & & Mishra et al. (2016) \\
\hline Deformed & P10 & $990 \pm 30$ & $989-1153$ & 1060 & \\
\hline Chalsa & & & & & Kumar et al. (2010) \\
\hline Deformed & $C-7$ & $840 \pm 30$ & $1059-1264$ & 1201 & \\
\hline Nameri & & & & & Kumar et al. (2010) \\
\hline Deformed & $\mathrm{N}-22$ & $895 \pm 35$ & $1039-1215$ & 1126 & \\
\hline \multirow[t]{2}{*}{ Harmutty } & & & & & Kumar et al. (2010) \\
\hline & $\mathrm{H} 13 \mathrm{~S}$ & $670 \pm 35$ & 1270-1394 & 1330 & \\
\hline
\end{tabular}

The recalibration is carried out through OxCal 4.2 online program; it provides the probable calendar date range along with the uncertainty and the mean value. All the ages are processed at $94.5 \%$ confidence level

be suggested that the frontal thrust (HFT) of entire Himalayan arc from northwest to northeast was ruptured by two giant earthquakes, i.e., 1255 and 1344 or $1408 \mathrm{AD}$, estimating the rupture length to be $\sim 800$ and $\sim 1000 \mathrm{~km}$, respectively, assigning a magnitude of $8.5 \leq M_{\mathrm{w}} \leq 9.0$ to these earthquakes (Fig. 5a). A wellestablished correlation exists between the rupture length and the magnitude of the earthquakes (Wells and Coppersmith 1994; Murotani et al. 2013). By increasing the rupture length of an earthquake, we are indirectly increasing the magnitude in turn surging the seismic hazards associated with that earthquake for a country like India, where the population is showing a rampant growth. 


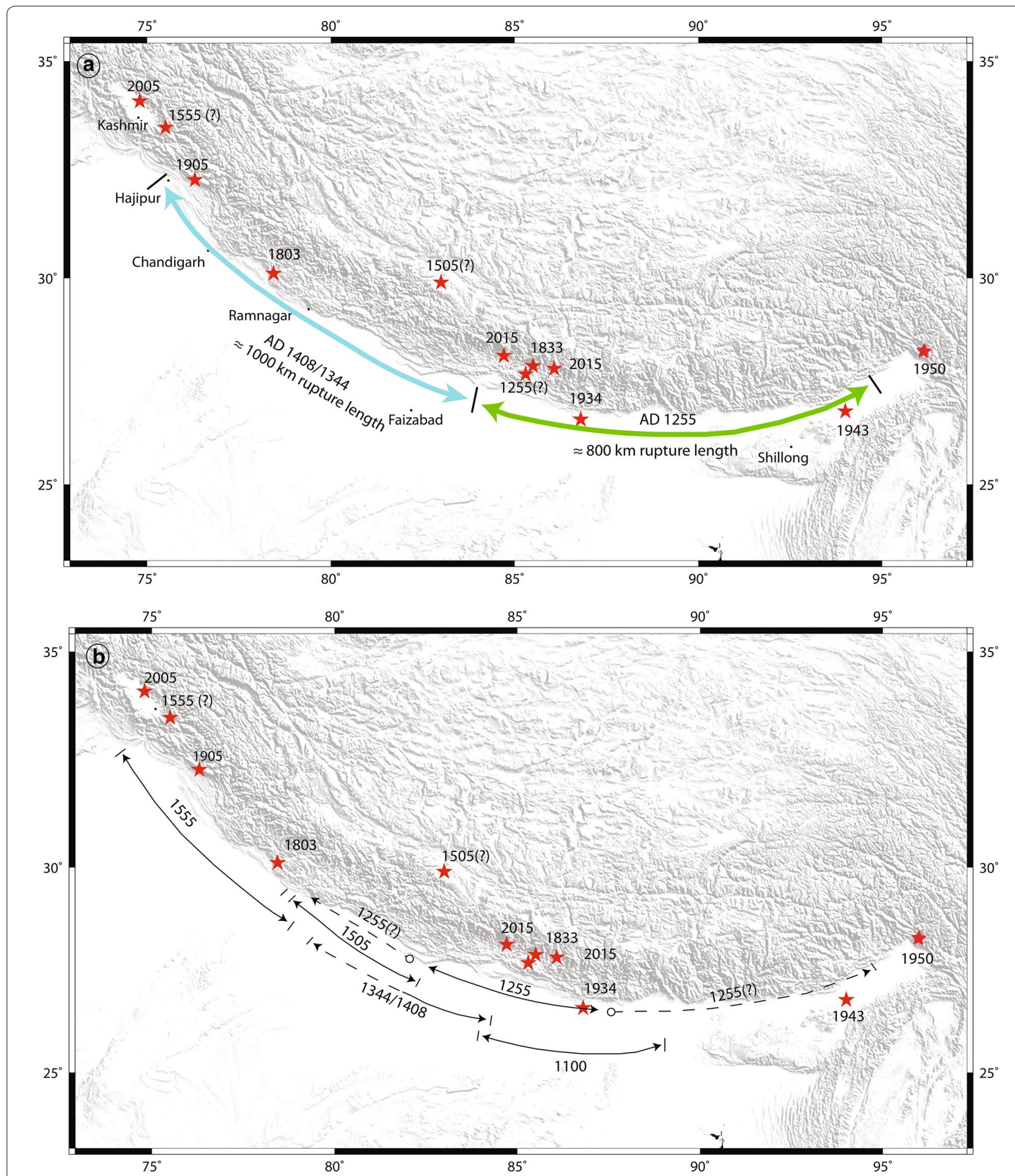

Fig. 5 a Map showing extent of the surface rupture of 1255 AD and 1344/1408 AD events postulated by previous workers. Keeping in mind the limitation with error bar in ages, the extent could be misleading and overestimating the seismic hazard in Himalaya. b Map showing the overlap in estimated surface rupture of the historical earthquakes and the uncertainty associated with extending the surface rupture of each event 
Now, if we consider the large magnitude earthquakes viz. 1905 Kangra earthquake (Mw 7.8), 1934 Bihar-Nepal (Mw 8.1) and 1950 Assam (Mw 8.4), then all these events range in a time frame of within 45 years. It is very much likely that if these earthquakes are dated 100 years from now, they will be considered as one giant earthquake rupturing the entire Himalayan arc. Therefore, with the constraints and resolution of dating techniques ultimately, we will be overestimating the seismic hazard in the Himalaya. The age of the surface ruptures of the historical earthquakes is poorly constrained and no surface rupture chronology with less than \pm 30 years of uncertainty has emerged so far. Another misleading point, which should be considered is assigning the youngest age to the event identified from the trenches without any capping unit. Careful reconsideration of the work at Chalsa and Nameri (Kumar et al. 2010) in eastern Nepal, the bracketing age in the trench, suggests 1154-1264 AD (mean 1201 AD) and 1039-1215 AD (mean 1126 AD) increasing the possibility of $1100 \mathrm{AD}$ event instead of $1255 \mathrm{AD}$ event, making it even more difficult to delineate the two events from the trench (Table 1). In the northwestern Himalaya at Hajipur, Chandigarh, Kala Amb, and Lal Dang, the ages assigned to surface rupture are 1426-1700, 1270-1397, 1404-1628, and 1282-1632 AD, respectively (Table 1 ) in which 1408,1505 , and $1555 \mathrm{AD}$ event can be tactfully fit-in. This would in turn change the overall scenario of seismic hazard along the entire Himalaya (Fig. 5b). Thus, it can be suggested that Himalayan front ruptured by multiple events in small patches. The average rupture length on the basis of the concrete evidences from the trenches has been assumed to around 300-350 km. From the Wells and Coppersmith (1994) magnitude and length relationship for all rupture types, the expected magnitude of earthquake is calculated to be around Mw 7.9-8.0 confuting the possibility of Mw 9.0 in the Himalaya. This view is supported by an argument that entire Himalayan arc is segmented into several blocks making it unlikely for the presence of any longer segment which could rupture to produce Mw 9 earthquake (Gupta and Gahalaut 2015).

\section{Conclusion}

One of the most robust conclusions that can be drawn from this work is that there were multiple events with overlapping surface ruptures along the HFT in the western, central, and eastern Himalaya. Interpreting that whole of the Himalayan front ruptured in two or three earthquakes is ambiguous and needs more extensive research work to verify this postulation. From our analysis, it can be ascertained that Himalayan front was ruptured by multiple events in small patches with an average rupture length of $\sim 300 \mathrm{~km}$, limiting earthquakes with a magnitude of $\mathrm{Mw}$ 7.9-8.0. The $1255 \mathrm{AD}$ medieval earthquake reported in Kathmandu Valley ruptured at least $350 \mathrm{~km}$ of the Himalayan frontal arc from Koliabas to Bardibas in eastern Nepal. For 1555 AD, Kashmir earthquake more work is required to precisely comment on the extent of surface rupture. For 1408/1344 $\mathrm{AD}$ earthquake, there could be two scenarios, either it ruptured the entire $\sim 1000 \mathrm{~km}$ of the Himalayan arc from Kathmandu to Hajipur or there were two separate events with a range of $1450 \pm 50 \mathrm{AD}$ in the 15th century. The northwest Himalaya, except one hinterland 1905 AD Kangra earthquake, has not experienced any recent large magnitude earthquake after 1344, 1505, and 1555 AD events. Since then, around 600 years have passed, and thus, a possibility of occurrence of a large or great magnitude earthquake in this region cannot be ruled out.

\section{Abbreviations}

MHT: Main Himalayan Thrust; JMT: Jawalamukhi Thrust; NaT: Nalagarh Thrust: BaT: Barsar Thrust; PaT: Palampur Thrust; BT: Bilaspur Thrust; CKF: Central Kashmir Fault; MBT: Main Boundary Thrust; HFT: Himalayan Frontal Thrust; STD: South Tibetan Detachment; MCT: Main Central Thrust; KVF: Kangra Valley Fault; PGF: Pinjore Garden Fault.

\section{Acknowledgements \\ Financial support received from the Ministry of Earth Sciences (MoES), New Delhi (MoES/PO(Seismo)/1(271)/AFM/2015) towards an Integrated Active Fault Mapping (AFM) project is duly acknowledged. We are thankful to Dr. Hisao Kondo for providing us valuable comments and suggestions, which enormously helped us improving our manuscript. We also acknowledge the comments/suggestions by the anonymous reviewer.}

\section{Author's contributions}

SA and JNM conceived the research concept. We complied all available data and tried to reinterpret the interpretation made by earlier worker suggesting the occurrence of giant earthquakes. All authors read and approved the final manuscript.

\section{Competing interests}

The authors declare that they have no competing interests.

\section{Funding}

Financial support received from the Ministry of Earth Sciences (MoES), New Delhi (MoES/P.O.(Seismo)/1(271)/AFM/2015) towards an Integrated Active Fault Mapping (AFM) project is duly acknowledged.

\section{Publisher's Note}

Springer Nature remains neutral with regard to jurisdictional claims in published maps and institutional affiliations.

Received: 2 November 2016 Accepted: 11 August 2017

Published online: 08 September 2017

\footnotetext{
References

Ahmad S, Bhat MI (2012) Tectonic geomorphology of the Rambiara basin, SW Kashmir Valley reveals emergent out-of-sequence active fault system. Himal Geol 33:162-172
} 
Ahmad A, Bhat Ml, Madden C, Bali BS (2013) Geomorphic analysis reveals active tectonic deformation on the eastern flank of the Pir Panjal Range, Kashmir Valley, India. Arab J Geosci. doi:10.1007/s12517-013-0900-y

Alam A, Ahmad S, Bhat SM, Ahmad B (2015) Tectonic evolution of Kashmir basin in northwest Himalayas. Geomorphology 239:114-126. doi:10.1016/j.geomorph.2015.03.025

Ambraseys N, Bilham R (2000) A note on the Kangra Ms -7:8 earthquake of 4 April 1905. Curr Sci 79:45-50

Ambraseys NN, Douglas J (2004) Magnitude calibration of north Indian earthquakes. Geophys J Int 158:1-42

Banerjee P, Bürgmann R (2002) Convergence across the northwest Himalaya from GPS measurements. Geophys Res Lett 29(13):1652. doi:10.1029/20 02GL015184

Bilham R (1995) Location and magnitude of the 1833 Nepal earthquake and its relation to the rupture zones of contiguous great Himalayan earthquakes. Curr Sci 69:101-128

Bilham R (2004) Earthquakes in India and the Himalaya: tectonics, geodesy and history. Ann Geophys 47:839-855

Bilham R, Wallace K (2005) Future Mw > 8 earthquakes in the Himalaya: implications from the 26 Dec $2004 \mathrm{Mw}=9.0$ earthquake on India's eastern plate margin. Geol Surv India Spl Publ 85:1-14

Bilham R, Blume F, Bendick R, Gaur VK (1998) Geodetic constraints on the Translation and Deformation of India: implications for future great Himalayan earthquakes. Curr Sci 74(3):213-229

Bilham R, Gaur VK, Molnar P (2001) Himalayan seismic hazard. Science 293:1442-1444

Bollinger L, Sapkota SN, Tapponnier P, Klinger Y, Rizza M, Van Der Woerd J, Tiwari DR, Pandey R, Bitri A, Bes de Berc S (2014) Estimating the return times of great Himalayan earthquakes in eastern Nepal: evidence from the Patu and Bardibas strands of the Main Frontal Thrust. J Geophys Res Solid Earth 119:7123-7163

Bollinger L, Tapponnier P, Sapkota SN, Klinger Y (2016) Slip deficit in central Nepal: omen for a repeat of the 1344AD earthquake? Earth Planets Space 68:1-12. doi:10.1186/s40623-016-0389-1

Campbell A (1833a) Account of the earthquake at Kathmandu. J Asiatic Soc Bengal 2(misc. II):564-567

Campbell A (1833b) Further particulars of the earthquake in Nepal. J Asiatic Soc Bengal 2(misc. Vl):636-639

Chitrakar GR, Pandey MR (1986) Historical earthquakes of Nepal. Bull Geol Soc Nepal 4:7-8

Dar RA, Romshoo SA, Chandra R, Ishtiaq A (2014) Tectono-geomorphic study of the Karewa Basin of Kashmir Valley. J Asian Earth Sci 92:143-156

Delcaillau B, Carozza JM, Laville E (2006) Recent fold growth and drainage development: the Janauri and Chandigarh anticlines in the Siwalik foothills, northwest India. Geomorphology 76:241-256

DeMets C, Gordon RG, Argus DF, Stein S (1994) Effects of recent revisions to the geomagnetic reversal time scale on estimates of current plate motion. Geophys Res Lett 94:17561-17579

DPNet Nepal Report (2015) Historical earthquakes in Nepal, disaster preparedness network Nepal, 2015. http://www.dpnet.org.np/index. php?pageName=earthquake. Accessed 6 Sept 2017

Dunn JA, Auden JB, Ghosh AHM, Roy SC, Wadia DN (1939) The Bihar-Nepal Earthquake of 1934. Geol Surv India Memoir 73:1-391

Feldl N, Bilham R (2006) Great Himalayan earthquakes and the Tibetan plateau. Nature 444(7116):165-170

Gavillot Y, Meigs A, Yule D, Heermance R, Rittenour T, Madugo C, Malik M (2016) Shortening rate and Holocene surface rupture on the Riasi fault system in the Kashmir Himalaya: active thrusting within the Northwest Himalaya orogenic wedge. Geol S Am Bull. doi:10.1130/B31281.1

Gupta H, Gahalaut VK (2014) Seismotectonics and large earthquake generation in the Himalayan region. Gondwana Res 25(1):204-213. doi:10.1016/j. gr.2012.11.006

Gupta HK, Gahalaut VK (2015) Can an earthquake of Mw 9 occur in the Himalayan region? Geol Soc London Special Publ 412(1):43-53. doi:10.1144/ sp412.10

Hayes GP, Briggs RW, Barnhart WD, Yeck WL, McNamara DE, Wald DJ, Nealy JL, Benz HM, Gold RD, Jaiswal KS, Marano K, Earle PS, Hearne MG, Smoczyk GM, Wald LA, Samsonov SV (2015) Rapid characterization of the 2015 Mw 7.8 Gorkha, Nepal, earthquake sequence and its seismotectonic context. Seismol Res Lett 86(6):1557-1567. doi:10.1785/0220150145
Hossler T, Bollinger L, Sapkota SN, Lavé J, Gupta RM, Kandel TP (2016) Surface ruptures of large Himalayan earthquakes in Western Nepal: evidence along a reactivated strand of the Main Boundary Thrust. Earth Planet Sci Lett. doi:10.1016/j.epsl.2015.11.042

lyengar RN, Sharma D, Siddiqui JM (1999) Earthquake history of Indian medieval times, Indian. J Hist Sci 34:181-237

Jayangondaperumal R, Kumahara Y, Thankur VC, Kumar A, Srivastava P, Shubhanshu D, Joevivek V, Dubey AK (2016) Great earthquake surface rupture along backthrust of the Janauri anticline. NW Himalaya J Asian Earth Sci. doi:10.1016/j.jseaes.2016.05.006

Kaneda H, Awata Y, Nakata T, Tsutsumi H, Awan AA, Hussain A, Khattak W, Ashraf M, Yeats RS, Baig MS (2006) Extensive surface fault rupture associated with the 2005 Mw 7.6 Pakistan earthquake. Abstract, 3rd Annual Meeting AOGS, Singapore

Kaneda H, Nakata T, Tsutsumi H, Kondo H, Sugito N, Awata Y, Akhtar SS, Khattak W, Awan AA, Yeats RS, Hussain A, Ashraf A, Wesnousky SG, Kausar AB (2008) Surface rupture of the 2005 Kashmir, Pakistan earthquake and its active tectonics implications. Bull Seismol Soc Am 98:521-557

Khattri KN (1987) Great earthquakes, seismicity gaps and potential for earthquake disaster along the Himalaya plate boundary. Tectonophysics 138(1):79-92

Khattri KN, Tyagi AK (1983) Seismicity patterns in the Himalayan plate boundary and identification of areas of high seismic potential. Tectonophysics 96:281-297

Kondo H, Nakata T, Akhtar SS, Wesnousky SG, Sugito N, Kaneda H, Tsutsumi H, Khan AH, Khattak W, Kausar AB (2008) Long recurrence interval of faulting beyond the 2005 Kashmir earthquake around the northwestern margin of the Indo-Asian collision zone. Geology 36(9):731-734. doi:10.1130/ G25028A.1

Kumahara Y, Jayangondaperumal R (2013) Paleoseismic evidence of a surface rupture along the northwestern Himalayan Frontal Thrust (HFT). Geomorphology 180:47-56

Kumar S, Mahajan AK (2001) Seismotectonics of the Kangra region, Northwest Himalaya. Tectonophysics 331(4):359-371

Kumar S, Wesnousky WG, Rockwell TK, Ragona D, Thakur VC, Seitz GG (2001) Earthquake recurrence and rupture dynamics of Himalayan Frontal Thrust, India. Science 294:2328-2331

Kumar S, Wesnousky SG, Rockwell TK, Briggs RW, Thakur VC, Jayangondaperumal R (2006) Paleoseismic evidence of great surface rupture earthquakes along the Indian Himalaya. J Geophys Res 111:B03304. doi:10.1029/200 4JB003309

Kumar S, Wesnousky SG, Jayangondaperumal R, Nakata T, Kumahara Y, Singh V (2010) Paleoseismological evidence of surface faulting along the northeastern Himalayan front, India: timing, size, and spatial extent of great earthquakes. J Geophys Res 115:B12422. doi:10.1029/2009JB006789

Kundu B, Yadav RK, Bali BS, Chowdhury S, Gahalaut VK (2014) Oblique convergence and slip partitioning the NW Himalaya: implications from GPS measurements. Tectonics 3:1-12

Lavé J, Avouac JP (2000) Active folding of fluvial terraces across the Siwaliks Hills, Himalayas of central Nepal. J Geophys Res 105(B3):5735-5770

Lavé J, Yule D, Sapkota S, Basant K, Madden C, Attal M, Pandey R (2005) Evidence for a Great Medieval Earthquake (1100 AD) in the Central Himalayas, Nepal. Science 307:1302-1305

Madden C, Ahmad S, Meigs A (2011) Geomorphic and paleoseismic evidence for late Quaternary deformation in the southwest Kashmir Valley, India: out-of-sequence thrusting, or deformation above a structural ramp? AGU abstracts T54B-07

Malik JN (2006) Active fault along Northwestern Himalayan Foothill Zone: implications to the Great Himalayan earthquakes. Technical report submitted to Department of Science and Technology, New Delhi, pp 34

Malik JN, Mathew G (2005) Evidence of paleoearthquakes from trench investigations across Pinjore Garden fault in Pinjore Dun, NW Himalaya. J Earth System Sci 114(4):387-400

Malik JN, Mohanty C (2007) Active tectonic influence on the evolution of drainage and landscape: geomorphic signatures from frontal and hinterland areas along Northwestern Himalaya, India. J Asian Earth Sci 29(5-6):604-618

Malik JN, Nakata T (2003) Active faults and related Late Quaternary deformation along the northwestern Himalayan Frontal Zone, India. Ann Geophys 46(5):917-936 
Malik JN, Nakata T, Philip G, Suresh N, Virdi NS (2008) Active fault and paleoseismic investigation: evidence of historic earthquake along Chandigarh Fault in the frontal Himalayan zone, NW India. J Himal Geol 29(2):109-117

Malik JN, Sahoo AK, Shah AA, Shinde DP, Juyal N, Singhvi AK (2010a) Paleoseismic evidence from trench investigation along Hajipur fault, Himalayan frontal thrust, NW Himalaya: implication of the faulting pattern on landscape evolution and seismic hazard. J Struct Geol 32:350-361

Malik JN, Shah AA, Sahoo AK, Puhan B, Banerjee C, Shinde DP, Juyal N, Singhvi AK, Rath SK (2010b) Active fault, fault growth and segment linkage along the Janauri anticline (frontal foreland fold), NW Himalaya, India. Tectonophysics 483:327-343. doi:10.1016/j.tecto.2009.10.028

Malik JN, Sahoo S, Satuluri S, Okumura K (2015) Active Fault and Paleoseismic Studies in Kangra Valley: evidence of Surface Rupture of a Great Himalayan 1905 Kangra Earthquake (Mw 7.8), Northwest Himalaya, India 105. Bull Seismol Soc Am 105(5):2325-2342

Malik JN, Naik SP, Sahoo S, Okumura K, Mohanty A (2016) Paleoseismic evidence of the $1505 \mathrm{CE}(?)$ and $1803 \mathrm{CE}$ earthquake from the foothill zone of the Kuman Himalaya along the Himalayan frontal thrust (HFT), India. Tectonophysics. doi:10.1016/j.tecto.2016.07.026

Martin S, Szeliga W (2010) A catalog of felt intensity data for 570 earthquakes in India from 1636 to 2009. Bull Seism Soc Am 100(2):562-569

Meigs A, Madden C, Yule JD, Gavillot Y, Hebeler A, Hussain A, Bhat MI, Kausar AB, Malik M, Ramzan S (2012) Pattern, rate, and timing of surface rupturing earthquakes across the northwest Himalaya. J Himal Earth Sci 45:111-114

Middlemiss CS (1910) The Kangra Earthquake of 4 April 1905. Mem geol Surv India 38:405

Mishra R, Singh I, Pandey A, Rao PS, Sahoo HK, Jayangondaperumal R (2016) Paleoseismic evidence of a giant medieval earthquake in the eastern Himalaya. Geophys Res Lett 43(11):5707-5715. doi:10.1002/201 6GL068739

Molnar P, Tapponnier P (1977) The collision between India and Eurasia. Sci Am 236(4):30-41

Mugnier JL, Leturmy P, Mascle G, Huyghe P, Chalaron E, Vidal G, Husson L, Delcaillau B (1999) The Siwaliks of western Nepal: I. Geometry and kinematics. J Asian Earth Sci 17:629-642

Mugnier JL, Huyghe P, Gajurel AP, Becel D (2005) Frontal and piggy-back seismic ruptures in the external thrust belt of western Nepal. J Asian Earth Sci 25:707-717

Mugnier JL, Huyghe P, Gajurel AP, Upreti BN, Jouanne F (2011) Seismites in the Kathmandu basin and seismic hazard in central Himalaya. Tectonophysics 509(1):33-49

Mugnier JL, Gajurel A, Huyghe P, Jayangondaperumal R, Jouanne F, Upreti B (2013) Structural interpretation of the great earthquakes of the last millennium in the central Himalaya. Earth Sci Rev 127:30-47

Murotani S, Satake K, Fujii Y (2013) Scaling rela-tions of seismic moment, rupture area, average slip, and asperity size for M?9 subduction-zone earth-quakes. Geophys Res Lett 40(19):5070-5074. doi:10.1002/grl.50976

Nakata T (1972) Geomorphic history and crustal movements of foothills of the Himalaya. Inst of Geography, Tohuku Univ., Sendai, p 77

Nakata T (1989) Active faults of the Himalaya of India and Nepal. Geol Soc Am Bull Special Paper 232:243-264

Oldham T (1883) Catalogue of Indian earthquakes from the earliest time to the end of AD Omen for a repeat of the 1344AD earthquake? Earth Planets Space 68:1-12

Pandey MR, Molnar P (1988) The distribution of intensity of the Bihar-Nepal earthquake of 15 January 1934 and bounds on the extent of the rupture zone. J Geol Soc Nepal 5:22-44

Pandey MR, Tandukar RP, Avouac JP, Lavé J, Massot JP (1995) Evidence for recent interseismic strain accumulation on a mid-crustal ramp in the Central Himalaya of Nepal. Geophys Res Lett 22:751-758

Pant MR (2002) A step toward a historical seismicity of Nepal. Adarsa 2:29-60
Phillip G, Suresh N, Bhakauni SS, Gupta V (2011) Paleoseismic investigation along Nalagarh Thrust: evidence of Late Pleistocene earthquake in Pinjaur Dun, Northwest sub-Himalaya. J Asian Earth Sci 40:1056-1067

Powers PM, Lillie RJ, Yeats RS (1998) Structure and shortening of the Kangra and Dehra Dun Reentrants, Sub Himalaya, India. Geol Soc Am Bull 110:1010-1027

Raiverman V, Srivastava AK, Prasad DN (1994) Structural style in northwestern Himalayan foothills. J Him Geol 15:263-282

Rajendran CP, John B, Rajendran K (2015) Medieval pulse of great earthquakes in the central Himalaya: viewing past activities on the frontal thrust. J Geophys Res 120(3):1623-1641

Ramsay CB (1995) Radiocarbon calibration and analysis of stratigraphy: the OxCal program. Radiocarbon 37(2):425-430

Ramsay CB, Scott M, Plicht H (2013) Calibration for archaeological and environmental terrestrial samples in the time range $26-50 \mathrm{ka}$ cal B.P. Radiocarbon 55(4):2021-2027

Sapkota SN, Bollinger L, Klinger Y, Tapponnier P, Gaudemer Y, Tiwari D (2013) Primary surface ruptures of the great Himalayan earthquakes in 1934 and 1255. Nat Geosci 6:71-76

Seeber L, Armbruster JG (1981) Great detachment earthquakes along the Himalayan arc and long-term forecasting. In: Simpson DW, Richards PG (Eds), Earthquake Prediction: An International Review AGU 4: 259-279

Shabir A, Bhat MI (2012) Tectonic geomorphology of the Rambiara basin, SW Kashmir Valley reveals emergent out-of-sequence active fault system. Himal Geol 33:162-172

Shah AA (2015) Kashmir Basin Fault and its tectonic significance in NW Himalaya, Jammu and Kashmir, India. Int J Earth Sci 104(7):1901-1906

Singh V, Tandon SK (2008) The Pinjaur dun (intermontane longitudinal valley) and associated active mountain fronts, NW Himalaya: tectonic geomorphology and morphotectonic evolution. Geomorphology 102:376-394

Suresh N, Bagati TN, Rohtash K, Thakur VC (2007) Evolution of Quaternary alluvial fans and terraces in the intramontane Pinjaur dun, sub-Himalaya, NW India: interaction between tectonics and climate change. Sedimentology 54:809-833

Thakur VC, Jayangondaperumal R, Malik MA (2010) Redefining MedlicottWadia's main boundary fault from Jhelum to Yamuna: an active fault strand of the main boundary thrust in northwest Himalaya. Tectonophysics 489:29-42

Upreti BN, Nakata T, Kumahara Y, Yagi H, Okumura K, Rockwell TK, Virdi NS, Maemoku H (2000) The latest active faulting in southeast Nepal. Proceedings of the Hokudan International Symposium and School in Active Faulting pp. 533-536

Valdiya KS (1980) The two intracrustal boundary thrusts of the Himalaya. Tectonophysics 66:323-348

Valdiya KS (1992) The main boundary thrust zone of Himalaya, India. Ann Tectonicae 6:54-84

Vassallo R, Mugnier JL, Vignon V, Malik MA, Jayangondaperumal R, Srivastava P, Jouanne F, Carcaillet J (2015) Distribution of the Late-Quaternary deformation in Northwestern Himalaya. Earth Planet Sci Lett 411:241-252

Wells DL, Coppersmith KJ (1994) New empirical relationship among magnitude, rupture length, rupture width, rupture area, and surface displacement. Bull Seismol Soc Am 84(4):974-1002

Wesnousky SG, Kumar S, Mohindra R, Thakur VC (1999) Uplift and convergence along the Himalayan Frontal Thrust. Tectonics 18(6):967-976

Yeats RS, Nakata T, Farah A, Fort M, Mirza MA, Pandey MR, Stein RS (1992) The Himalayan frontal fault system. Ann Tecton 6:85-98

Yule D, Dawson S, Lavé J, Sapkota S, Tiwari D (2006) Possible evidence for surface rupture of the Main Frontal Thrust during the great 1505 Himalayan earthquake, far-western Nepal, in AGU Fall Meeting Abstracts, S33C-05: 1, 5

Zhao W, Nelson KD, Che J, Quo J, Lu D, Wu C, Liu X (1993) Deep seismic reflection evidence for continental underthrusting beneath southern Tibet. Nature 366:55-559 